\title{
COMMENTS
}

\section{MANAGEMENT, CONTROL, AND THE DILEMMAS OF PRESIDENTIAL LEADERSHIP IN THE MODERN ADMINISTRATIVE STATE}

\author{
DANIEL B. RODRIGUEZ $†$
}

\section{INTRODUCTION}

There is a growing degree of consensus for the proposition that all roads to regulatory reform lead to (or, perhaps more accurately, from) the President. ${ }^{1}$ Calls for regulatory reform emphasize that systematic direction from the executive branch is a key to disentangling regulatory gridlock and ossification. ${ }^{2}$ Even those

$\dagger$ Acting Professor of Law, Boalt Hall School of Law, University of California, Berkeley. This Comment is based on remarks presented at a symposium on the National Performance Review held at Duke University School of Law on January 20, 1994.

1. See, e.g., Alfred C. AMAN, JR., AdMinistrative LAW IN a Global ERA 121-25 (1992) (noting increased presidential control over the administrative process); Christopher F. EDley, JR, AdMINISTRATIVE LAW: RETHINkING JUdicial CONTROL OF BUREAUCRACY 246-47 (1990) (discussing the roles of the White House and the Office of Management and Budget (OMB) in regulatory review); Harold $\mathrm{H}$. Bruff. Presidential Management of Agency Rulemaking, 57 GEO. WASH. L. REv. 533, 552-62 (1989) (chronicling the increasing influence of OMB review); Philip J. Harter, Execulive Oversight of Rulemaking: The President Is No Stranger, 36 AM. U. L. REV. 557, 564-69 (1987) (arguing that presidential influence can give needed direction and cohesion to rulemaking); Jerry L. Mashaw, Prodelegation: Why Administrators Should Make Political Decisions, 1 J.L. ECON. \& ORGanization 81, $95-96$ (1985) [hereinafter Mashaw, Prodelegation] (arguing that broad delegations of power are justified because the President will be accountable to the electorate for implementing the delegations); Richard J. Pierce. Jr., The Role of Constitutional and Political Theory in Administrative Law, 64 TEX. L. REV. 469, 520-21 (1985) (arguing that the President's direct political accountability makes him ideal for exercising regulatory oversight); Peter L. Strauss \& Cass R. Sunstein. The Role of the President and $O M B$ in Informal Rulemaking, 38 ADMIN. L. REV. 181. 188-94 (1986) (arguing for the desirability of greater presidential control over regulation).

2. These calls have a long lineage. See, e.g., PERI E. ARNOLD, MAKING THE MANAGerial PREsidency 3-21 (1986) [hereinafter ARNold, MANAGerial PREsidency] (describing the connection between theories of public administration and a strong presidency in the late 19th-century United States); LEONARD D. WhITE, THE REPUBLICAN ERA: 1869-1901, at 20-44 (1958) (describing origins of the republican theory of the presidency). 
who are more skeptical about entrusting to the President the main decisions regarding the scope and direction of regulatory policymaking appreciate that presidential leadership is a fundamental element in the effort to reconfigure the structure of modern regulation and administration. ${ }^{3}$ The argument for a strong presidential role in public administration and regulation has rested on the perceived capabilities of the "chief administrator" to superintend the increasingly diffuse structure of modern federal regulation. ${ }^{4}$ Although the core of this argument grows out of views concerning the characteristics of the presidency as an institution, the argument rests also on views regarding the perceived inabilities of Congress and the bureaucracy to coordinate adequately regulatory policy. ${ }^{5}$

3. Two recent articles provide especially thorough and insightful contributions to the debate over the proper scope of presidential powers in the administrative state. See Abner S. Greene, Checks and Balances in an Era of Presidential Lawmaking, $61 \mathrm{U}$. CHI. L. REV. 123 (1994); Lawrence Lessig \& Cass R. Sunstein, The President and the Administration, 94 COLUM. L. REV. 1 (1994).

4. See, e.g., Lessig \& Sunstein, supra note 3, at 101-06. See generally Steven G. Calabresi \& Kevin H. Rhodes, The Structural Constitution: Unitary Executive, Plural Judiciary, 105 HARV. L. REV. 1153 (1992) (examining the theory and practice of congressional control over the executive and judicial branches). For an analysis of the historical underpinnings of the President's role as "chief administrator," see Saikrishna B. Prakash, Note, Hail to the Chief Administrator: The Framers and the President's Administrative Powers, 102 YALE L.J. 991 (1993).

5. This expanding scope of presidential power in the administrative state has not come without controversy. From the perspective of administrative law, two recent developments are noteworthy. Arguably the most significant step in the expansion of the President's powers over administration has been the capacious doctrine of Chevron, that is, the tendency of appellate courts to defer to the statutory interpretations of administrative agencies under the aegis of the executive branch. See Chevron U.S.A. Inc. v. Natural Resources Defense Council, Inc., 467 U.S. 837 (1984); see also Thomas W. Merrill, Judicial Deference to Executive Precedent, 101 YALE L.J. 969 (1992) (arguing that Supreme Court applications of Chevron have resulted in less deference to administrative interpretations and proposing an alternative model under which courts would treat administrative decisions as prima facie correct); Peter H. Schuck \& E. Donald Elliott, To the Chevron Station: An Empirical Study of Federal Administrative Law, 1990 DUKE L.J. 984 (reporting the results of a large-scale empirical study of direct appellate court review of federal agency actions and the influence of Chevron on courts of appeals); Cass R. Sunstein, Law and Administration After Chevron, 90 ColUM. L. REV. 2071 (1990) (analyzing Chevron as a kind of "counter-Marbury" for the administrative state). The other main source of controversy has been the expanding scope of regulatory review by institutions within the executive branch, such as the $\mathrm{OMB}$ and the Competitiveness Council. See, e.g., Clifford Krauss, House Votes to Eliminate Money for Regulatory Council Headed by Quayle, N.Y. TimES, July 2, 1992, at A16. The issues raised by these two developments have been different, yet there is a common thread running through critics' objections to both situations: that the chief executive's expanded role in the regulatory process comes at the expense of the separation of powers and, too frequently, at the expense of 
To assess the virtues of strong presidential leadership in the regulatory process, we need to have a richer sense of the dimensions of presidential leadership in regulatory decisionmaking. The set of proposals put forward by the National Performance Review (NPR), a task force established by the Clinton administration last year, provides a useful focal point for the examination of this issue. The NPR proposals reflect the attention paid in the modern administrative state to the role of the President in superintending the regulatory process. Although proposals of the NPR variety are championed by the President and his agents in the name of improving regulatory performance, there are elements of such strategies that raise more general questions concerning the role of the President in the modern regulatory process. It is to these questions that this Comment is directed. In Part I, I consider how the trend toward President-led initiatives fits with our growing skepticism about the capacities of legislators and bureaucrats to improve regulation and administration. In Part II, I trace some of the conceptual underpinnings of the President's expanding regulatory role. I add to this mostly theoretical discussion the particulars of the NPR Report in Part III. Ultimately, the Clinton administration's opening salvo into the thicket of regulatory reform is of a piece with contemporary trends in presidential politics and regulatory administration.

\section{INSTITUTIONAL CAPACITIES AND REGULATORY REFORM}

A growing chorus of critics charge that regulatory failure has gone well beyond administrative mismanagement. "Ossification," an apt description Tom McGarity uses to encompass a range of problems that afflict contemporary regulation, ${ }^{7}$ is a consequence

salutary regulatory policy.

6. See Richard A. HaRris \& SidNEy M. MILKIS, The Politics of Regulatory Change: A Tale of Two agencies 3-21 (1989); Cass R. Sunstein, After the RIGHTS REVOLUTION: RECONCEIVING THE REGULATORY STATE 74-110 (1990) [hereinafter SUNSTEIN, RIGHTS REVOLUTION]; Jerry L. Mashaw. Improving the Environment of Agency Rulemaking: An Essay on Management, Games, and Accountability, 57 LAW \& CONTEMP. PROBS., Spring 1994, at 185, 200-15, 218-22.

7. See generally Thomas O. McGarity, Some Thoughts on Deossifying the Rulemaking Process, 41 DUKE L.J. 1385 (1992) (discussing the evidence and causes of the "ossification" of the rulemaking process, as well as potential solutions to this phenomenon). 
of a complicated and overlapping series of problems, the solutions to which lie beyond paeans to good government. Exhortations to do a better regulatory job are likely to be seriously incomplete because many of the problems plaguing contemporary regulation are the products of severe institutional liabilities, that is, qualities of decisionmaking and political choice associated with politicians acting within their institutions. Conceptions of regulatory reform might strategically presuppose politicians working collectively, within Congress, the presidency, the bureaucracy, and the judiciary, to develop ideas and strategies to improve regulatory performance. If, however, we have a much more realistic view of the capacity of decisionmakers within these institutions to replace regulatory pathologies with effective public policy, then our prescriptive agenda will look quite different. In my view, the effort to graft prescriptions onto the contemporary structure of American political institutions and government must begin with an appreciation of the realpolitik of regulatory politics. In that connection, we would do well to understand the difficulties and dilemmas endemic to Congress and bureaucracy, the political institutions that are, along with the presidency, most critical to the success or failure of federal regulatory policy. ${ }^{8}$

As a preliminary matter, it should be acknowledged that the solutions to regulatory dilemmas rarely involve a choice for one institution over another. To emphasize the comparative advantages of the President in regulatory leadership is not to suggest that he can or should pursue reform unilaterally. Indeed, one theme undergirding calls for greater presidential intervention is some version of "all hands on deck;" suggestions for augmenting the President's role in the regulatory process are frequently joined with proposals for similarly expanding the role of the other two main branches of government, Congress and the judiciary. ${ }^{9}$

\section{A. Congressional Capabilities}

Because there is no doubt that the most comprehensive strategy for systematic regulatory reform would require significant statu-

8. See generally Daniel B. Rodriguez, The Positive Political Dimensions of Regulatory Reform, 72 WASH. U. L.Q. 1, 52-92 (1994) (examining the structure of Congress and the Presidency and their roles vis-à-vis administrative agencies).

9. See, e.g., Cass R. Sunstein, Constitutionalism After the New Deal, 101 HaRv. L. REV. 421, 463, 478 (1987). 
tory changes, Congress would seem to be a critical element in any President's reform agenda. Yet the NPR Report describes an agenda concerned almost entirely with executive branch initiatives. ${ }^{10}$ The principal problem with bringing Congress fully into efforts to improve regulatory systems is that legislators are unlikely to be reliable allies. Even worse, Congress may persistently stand in the way of completing the agenda for a regulatory program.

Congress's weaknesses as an instrument for comprehensive regulatory reform are manifold. To begin with, each legislator has a particular set of agendas, goals, and interests, and as a result, legislative incentives comprise all the goals of individual legislators. ${ }^{11}$ To move Congress toward regulatory reform, then, is to move key coalitions of legislators, coalitions made up of independent, calculating lawmakers acting in an environment with a rather weak potential for hierarchical control and discipline. The assertion that because legislators develop their own agendas and interests it is difficult to mobilize 535 of them in the direction of comprehensive reform is, all things considered, rather modest. We need not embrace any particular theory of legislative behavior-for instance, the view that legislators are motivated solely by the desire to become reelected ${ }^{12}$ - to believe that Congress is heterogeneous and, therefore, difficult to control and to lead. Rather, it is merely that the legislature is an unruly and far-flung lawmaking institution that has limited capacity to pursue systematic, focused regulatory change.

There is precious little reason to expect Congress to act with more collective dispatch than otherwise when the principal aim is to dissolve regulatory ossification. Even if the corrections lie in new and improved statutes, the legislature is still faced with the same essential structure of lawmaking. After all, some of the central features of the current regulatory predicament are the result

10. See OfFice of the Vice PRESIDENT. ACCOMPANYING REPORT OF THE NationAL PERFoRMANCE REVIEW: IMPROVING REgulatory SYSTEMS 17-73 (1993) [hereinafter IMPROVING REGULATORY SYSTEMS].

11. See Rodriguez, supra note 8, at 44-46. For contrary views that stress the ways in which Congress can function as a deliberative body, see Cass R. Sunstein, Interest Groups in American Public Law, 38 STAN. L. REv. 29 (1985).

12. See, e.g., David R. Mayhew, Congress: The Electoral Connection 5 (1974). 
of poorly designed statutes and inapt regulatory strategies. ${ }^{13}$ For instance, the requirement imposed by Congress on manufacturers through the Clean Air Act to use the "best available technology" in controlling air pollution limits the incentive for technological innovation. ${ }^{14}$ This regulatory paradox is not a consequence of flawed implementation but, instead, of political choices reflected in the statute's design. ${ }^{15}$ At the very least, such regulatory "mismatches" or "paradoxes" reflect legislators' apparent difficulty in constructing sensible regulatory policy. ${ }^{16}$ And, at worst, these problems suggest something more problematic about the structure of legislative behavior and policymaking strategies. Enacting sound regulatory legislation is difficult in a lawmaking environment of hundreds of legislators with competing interests and of institutions that block creative legislative initiatives. ${ }^{17}$ The situation in Congress is twice vexing: the diffuse nature of congressional decisionmaking has contributed to the problems plaguing contemporary regulation, and to make matters worse, this diffusion renders Congress nearly helpless to fix what it is partially responsible for breaking. ${ }^{18}$

Some of the difficulties legislators face in constructing a strategy that aims at least as high as the NPR proposals arise from legislators' lack of mcentives to take the lead in reforming administrative government. To the extent that legislators are making political assessments, they are unlikely to see substantial advantages from regulatory reorganization or government streamlining. The problem is not that legislators are predictably opposed to

13. See SunStein, Rights Revolution, supra note 6, at 84-97.

14. See Bruce A. Ackerman \& Richard B. Stewart, Reforming Environmental Law, 37 Stan. L. REv. 1333 (1985); Cass R. Sunstein, Paradoxes of the Regulatory State, 57 U. CHI. L. REV. 407, 420-21 (1990) [hereinafter Sunstein, Regulatory State].

15. See Sunstein, Regilatory State, supra note 14.

16. See, e.g., STEPHEN BREYER, REgUlATION AND ITS REFORM 108, 191-96 (1982); see also Rodriguez, supra note 8 , at 11-16.

17. See Rodriguez, supra note 8, at 106-11.

18. One possible response to this diffusion is to strengthen leadership within Congress. An important theme in the literature on Congress and its institutional structure regards the difficulties legislators face in constructing stable patterns of leadership (for instance, through strong parties) that might overcome some of the difficulties facing a heterogenous legislature. See, e.g., Michael Fitts, The Vices of Virtue: A Political Party Perspective on Civic Virtue Reforms of the Legislative Process, 136 U. PA. L. REV. 1567 (1988); Charles O. Jones, Joseph G. Cannon and Howard W. Smith: An Essay on the Limits of Leadership in the House of Representatives, in CONGRESS: STRUCTURE AND POLICY 260 (Mathew D. McCubbins \& Terry Sullivan eds., 1987). 
reforming administrative government; Congress has shown that it sometimes is prepared to accept a legislative proposal formulated by agents of the executive branch. ${ }^{19}$ Rather, legislators simply may perceive themselves as having better things to do than invest their resources and energies into the reorganization of the government.

Furthermore, legislators have a fairly limited issue horizon. The reform proposals in the NPR Report aim for systematic structural change. They involve different regulatory programs and an eclectic collection of issues and concerns. For example, the recommendation listed as "REG08," to improve regulatory science proposes to change the way all relevant agencies evaluate science and scientific considerations. ${ }^{20}$ The creation of the proposed National Science and Technology Council would presumably offer systematic scientific advice to agencies across the regulatory board. And the proposed interagency Regulatory Coordinating Group (REG01) would "share imformation and coordinate approaches to regulatory issues"21 and therefore would offer a more overarching structure for the making of regulatory policy. ${ }^{22}$ By contrast, Congress seldom legislates in a systematic, multi-agency, multi-issue way; it rarely deals with the subject of regulation writ large. Instead, it deals with regulatory and administrative agencies as they arise in connection with particular agencies and programs. And even where Congress has passed "reorganization" statutes, the effect of reorganization has been to change the way the legislature does its business internally. Although the issues are complex and crosscutting, the resulting institutional changes are still confined to Congress. $^{23}$

19. See, e.g., ARNold, MANAgerial PresidenCY, supra note 2, at 103-15, 200-03 (describing legislative adoptions of executive branch reorganization initiatives).

20. See IMPROVING REGULATORY SYSTEMS, supra note 10, at 59-63. This recommendation proposes the creation of a National Science and Technology Council, which would represent a reconstituted Federal Coordinating Council for Science. Engineering and Technology. Id. at 61,63 n.29.

21. Id. at 20.

22. Id. at 17-22. See generally STEPHEN BREYER, BREAKING THE VICIOUS CIRCLE: TOWARD EFFECTIVE RISK REGULATION 64-72 (1993) [hereinafter BREYER, VICIOUS CIRCLE] (describing proposal for centralized, interagency group to coordinate approaches to risk regulation).

23. For discussions of intra-legislative reform, see Roger H. Davidson, The Emergenee of the Postreform Congress, in THE POSTREFORM CONGRESS 3 (Roger H. Davidson ed., 1992); Kenneth A. Shepsle, The Changing Textbook Congress, in CAN THE GOVERNMENT Govern? 238, 248-56 (John E. Chubb \& Paul E. Peterson eds., 1989). 
In addition, the legislature tends to have a short time horizon. Legislators construct regulatory programs in certain ways and for certain purposes in the shadow of the current political and social environment. At some level, Congress's short time horizon reflects that legislators have other thimgs to accomplish, including both lawmaking and non-lawmaking activities. ${ }^{24}$ Indeed, the decision to entrust the substance of the regulatory program to an administrative agency rather than to more precise legislation reflects, in part at least, a desire to leave the program's future to another institution. ${ }^{25}$ But there may well be a more affirmative purpose behind the legislature's resistance to looking too far ahead. Leaving the program's mandates ambiguous, with flexibility, acknowledges the fact, among others, that circumstances may change in the future; they may change in a way that makes existing regulatory strategies anachronistic. ${ }^{26}$ Moreover, legislators' policy preferences may change, and along with them, their views about appropriate regulatory strategy. ${ }^{27}$ Legislators frequently resist tying themselves to the mast through precise legislation for fear of limiting their capacities to change with the times. This is the standard story of broad delegations in the modern administrative state. ${ }^{28}$

In evaluating regulatory policy, we should keep in mind that such policy is made in the shadow of two legislatures. ${ }^{29}$ One is the institution that enacted the statute. Its preferences are enshrined in the statute. However ambiguous this encapsulation, the

24. See, e.g., MORRIS P. FIORINA. CONGRESS: Keystone OF THE WASHINGTON EsTABLISHMENT 37-47 (2d ed. 1989).

25. See, e.g., Edward L. Rubin, Law and Legislation in the Administrative State, 89 COLUM. L. REV. 369, 374 (1989).

26. On the role of flexibility as an explanation for legislative delegation of power, see Peter H. Aranson et al.. $A$ Theory of Legislative Delegation, 68 CORNELL L. REv. 1 (1982); Mashaw, Prodelegation, supra note 1, at 91-95.

27. There may be many different reasons for these changes in preferences, including changing constituent preferences and the emergence of new technologies. See R. DOUGLAS ARNOLD, THE LOGIC OF CONGRESSIONAL ACTION 60-87 (1990) [hereinafter ARNOLD, CONGRESSIONAL ACTION] (discussing the sources of legislators' policy preferences).

28. See Rubin, supra note 25, at 374; Mashaw, Prodelegation, supra note 1, at 91-95; Aranson et al., supra note 26.

29. Murray J. Horn \& Kenneth A. Shepsle, Commentary on "Administrative Arrangements and the Political Control of Agencies": Administrative Process and Organizational Form as Legislative Responses to Agency Costs, 75 VA. L. REV. 499, 503-04 (1989); Kenneth A. Shepsle, Bureaucratic Drift, Coalitional Drift, and Time Consistency: A Comment on Macey, 8 J.L. ECON. \& ORganization 111, 114-15 (1992) [hereinafter Shepsle, Bulreaucratic Drift]. 
legislature that enacts the regulatory program casts a substantial shadow over the scope and direction of the program in the future. ${ }^{30}$ Indeed, agencies' and courts' struggles to discern what the enacting legislature intended, by resort to the text and legislative history of the statute, give a special pride of place to the preferences of the legislative coalition that enacted the statute. ${ }^{31}$ The other relevant legislature is the one that exists contemporaneously with the program under evaluation. This legislature may be, depending on the age of the regulatory program, made up of many of the same members of the original coalition that created the program, but there may be substantial differences in the extent of the legislature's current commitment to the program as constituted and as functioning. ${ }^{32}$ Moreover, legislator turnover may change the composition of the enacting coalition.

The most obvious way for this sitting legislature to turn its preferences into policy is by repealing or amending the statute. Legislative change is quite difficult, however. ${ }^{33}$ The institutional structure of Congress is designed to make legislative change extremely expensive to accomplish. ${ }^{34}$ Legislation that has lost current legislative support may still persist where legislative institutions, such as "gatekeeper" committees, restrictive amendment rules, and the presidential veto, stand in the way of change.

The ways legislators calculate how their regulatory preferences may change over time raises a final difficulty: Congress may actually benefit from some degree of regulatory ossification. Delays and barriers to the making and remaking of regulatory policy can frequently serve legislative goals. Although efforts to reform regulation often presuppose that legislators would profit from a recon-

30. See generally Peter L. Strauss. When the Judge Is Not the Primary Official with the Responsibility to Read Agency Interpretation and the Problem of Legislative History. 66 CHI.KenT L. REv. 312. 329-32 (1992) (describing influence of legislative history and direct political pressure over agencies).

31. See, e.g., id. at 329-31 (discussing agencies); Stephen Breyer, On the Uses of Legislative History in Interpreting Statutes, 65 S. CAL. L. REV. 845 (1992) (discussing courts).

32. See Shepsle, Bureaucratic Drift, supra note 29, at 114-15 (noting the "coalitional drift" regarding legislative preferences).

33. See Kenneth A. Shepsle, Institutional Equilibrium and Equilibrium Institutions, in Political SCience: The Science of Politics 51 (Herbert F. Weisberg ed., 1986).

34. See Kenneth A. Shepsle, Institutional Arrangements and Equilibrium in Multidimensional Voting Models, 23 AM. J. POL. SCI. 27 (1979); cf. Kenneth A. Shepsle \& Barry A. Weingast, Structure-Induced Equilibrium and Legislative Choice, 37 PUB. CHOICE 503, 511-14 (1981) (developing a theory of legislative stability). 
figured system in which regulatory policy is made more efficiently, inefficiencies in the system-inefficiencies that several of the NPR recommendations are designed to counteract ${ }^{35}$-may actually serve the interests of legislators. For example, administrative procedures that provide notice and a considerable delay between the announcement of a proposed policy and its implementation may generate legislative attention, enabling legislators concerned with this policy proposal to express their views to the appropriate agency officials. ${ }^{36}$ In this light, NPR's proposal for "Streamlining Agency Rulemaking Procedures" ${ }^{37}$ may actually disserve legislative aims. Accordingly, legislators may be reluctant to upset a procedural system that facilitates their influence over the regulatory process. Or, at the very least, Congress may hesitate to take the lead in restructuring regulatory systems when the impact of such reforms on legislators' abilities to further their own aims through the regulatory process is uncertain. ${ }^{38}$ Fear of the unknown may chill legislative initiatives toward improving regulatory processes.

\section{B. Bureaucratic Capabilities}

Agencies, so often identified as the principal sources of regulatory difficulties, have shown little propensity to reform themselves. Organizational norms and practices limit, for better or worse, the opportunities for significant changes in behavior, strategy, and internal agency structures. To begin with, bureaucrats have especially short time horizons. Agency leaders are in office only for relatively short periods of time. New administrators come in with their own ways of doing business, so even the most ingenious administrative innovations seldom have lasting effect. ${ }^{39}$ Regulato-

35. See, e.g., IMPROVING REgULATORY SYSTEMS. supra note 10, at 1 (describing the excessive complexity of some agency procedures).

36. See Mathew D. McCubbins et al., Administrative Procedures as Instnuments of Political Control, 3 J.L. ECON. \& ORGanIZATION 243, 253-64 (1987); Mathew D. McCubbins et al., Structure and Process, Politics and Policy: Adninistrative Arrangements and the Political Control of Agencies. 75 VA. L. REv. 431, 441-443 (1989).

37. IMPROVING REGULATORY SYSTEMS, supra note 10, at 41-46.

38. In this regard, it may be telling that the statute that lies at the core of the federal regulatory system. the Administrative Procedure Act, 5 U.S.C. $\S 551$ (1988), has remained almost completely free of legislative change, despite objections that it is anachronistic and incomplete. See Antonin Scalia, Vermont Yankee: The APA, the D.C. Circuit, and the Supreme Court, 1978 SUP. CT. REV. 345, 375-88.

39. The constant turnover in administrative agency leadership is likely to defeat one 
ry turbulence is the predictable result of a system in which policies are the product of agencies that undergo significant periodic realignment. It is not just that top agency personnel changes; rather, it is the combination of both turnover and political change. To the extent that agency personnel reflect the ideologies and political strategies of their principals in the legislative and executive branches, administrative agency policies will be unstable. At the same time, bureaucratic change is limited by the internal dynamics of the agencies' organizational structure and modes of operation. Changing in significant ways the patterns of administrative behavior through radical innovations is, as modern organizational theory makes clear, extraordinarily difficult. ${ }^{40}$

Even supposing that we could pursue reform from the bottom up, that is, by considering the internal characteristics of agencies and addressing some of the ways that organizational behavior and incentives resist innovation, we would still face the difficulty associated with the diffuse nature of the modern bureaucracy. Simply put, there are legions of agencies and regulatory programs, each with its own structure and (il)logic. Among the many consequences of this diffusion of regulatory responsibilities is the difficulty in developing methods of encouraging collaborative regulatory activities. Even when they are allowed by law to do so, agencies have few incentives to collaborate with one another to facilitate more interactive approaches to solving social and economic problems. Certain industries such as automobile manufacturing are regulated, as the NPR points out, by myriad different agencies. ${ }^{41}$

Coordination among agencies with intersecting concerns regarding the development of appropriate regulatory standards tvould seem sensible. These opportunities for mutual decision-

interesting initiative to introduce "Total Quality Management" concepts into federal administrative agencies. This idea was proposed by two influential scholars on regulation (who are, perhaps not coincidentally, also experienced organization managers). See E. Donald Elliott, TQM-ing the OMB: Or Why Regulatory Review Under Exectutive Order 12,291 Works Poorly and What President Clinton Should Do About It, 57 LAW \& CONTEMP. PROBS., Spring 1994, at 167; Paul R. Verkuil, Is Efficient Government an Oxymoron?, 43 DUKE L.J. 1221, 1232 (1994).

40. See, e.g., JAMES G. MARCH, DeCISIONS AND ORganizations (1988) (collecting various studies from organizational theorists); Robert T. Golembiewski, Public Sector Organization Behavior and Theory: Perspectives on Nagging Problems and on Real Progress, in Public Administration: THE STATE of THE Discipline 127 (Naomi B. Lynn \& Aaron Wildavsky eds., 1990) (discussing four different models of organizational theory).

41. See 1MProving Regulatory SyStems, supra note 10, at 17-18. 
making are rarely taken, however. Nor is collaboration common among agencies that have specifically overlapping jurisdiction over related subject matter. For instance, the recent controversy between the Securities and Exchange Commission and the Commodity Futures Trading Commission over the appropriate regulatory strategy with respect to "commodities" and "securities," which are under the aegis of both regulatory programs, illustrates the seeming intractability of agencies that should be working together toward a common purpose. ${ }^{42}$

Beyond habihities associated with the particular structure and organization of the agencies, the dynamics of the legislative process create a set of problems for agencies seeking to improve regulatory performance. ${ }^{43}$ Two problems especially deserve mention. Legislators must collaborate with one another to form a coalition to enact a regulatory program. Although legislators may have distinct preferences and intentions concerning the nature and scope of the program, they must finally agree on a version to enact into law. Once the statute is in place, though, legislators' heterogeneous preferences may be projected onto the agencies in the form of battles waged among the lawmakers about the direction of regulatory policy. Agencies are frequently caught in the middle of these intra-legislative disputes. In light of this, to suggest that agencies improve regulatory policy by, say, following exactly the intent of the statute is to underestimate the phenomenon of postenactment legislative battles over the meaning of the program's aims and the structure of implementation of the program.

A second problem that grows out of the dynamics of legislation regards the consequences for agency performance of the intertemporal quality of legislative preferences-what I described above as the shadow cast by the two legislatures. ${ }^{44}$ Under the traditional view of administrators as agents carrying out the will of

42. See Jonathan R. Macey, Organizational Design and Political Control of Administrative Agencies, 8 J.L. ECON. \& ORGANIZATION 93, $104-08$ (1992).

43. See Roger G. Noll, Economic Perspectives on the Politics of Regulation, in 2 HANDBOOK OF INDUSTRIAL ORGANIZATION 1253, 1278-80 (R. Schmalensee \& R. Willig eds., 1989) (discussing how the procedural requirements of regulatory legislation lead to bureaucratic obedience to the political coalition that enacted the legislation).

44. This is what Kenneth Shepsle usefully labels the phenomenon of "coalitional drift." See Shepsle, Bureaucratic Drift, supra note 29. See also supra text accompanying notes 29-34. 
legislative and executive principals as reflected in statutes and executive orders, administrators are responsible for obeying the mandates of the program as constructed by the enacting legislature. ${ }^{45}$ There is, however, a critical political element that complicates the administrator's task. Agencies carry out their functions in the shadow of the current legislature, an institution made up of members with individual goals and agendas. Hence, agencies are caught between two legislatures, that is, legislative preferences as expressed in the language and history of the regulatory program enshrined in the original statute, and the preferences of current legislators, expressed as the agency proceeds to implement and interpret their regulatory program. In these circumstances, agencies are unlikely to pursue regulatory reform initiatives that may have uncertain effects on the dilemma of this intertemporal legislative crossfire. ${ }^{46}$

The preceding discussion has highlighted the limited capacities of Congress and the bureaucracy to act as instruments of systematic regulatory reform. As noted earlier, none of these difficulties calls into question the rather obvious point that comprehensive reform must involve each branch of government. Viewing one institution as the exclusive locus of reform is myopic; the regulatory process is dynamic and interactive, and reform must incorporate richly developed theories and analyses of each institution-taken separately and as part of an interinstitutional system. Nonetheless, there is a trend in the normative scholarship on regulation and administration to embrace the institution of the presidency as the linchpin of regulatory reform. Such a view is undergirded both by positive theories of legislative and bureaucratic decisionmaking, as described above, and by emerging positive theories of presidential decisionmaking that stress the particular capacities of the President to lead regulatory reform.

45. See Strauss, supra note 30 , at 329-35.

46. This dilemma is especially difficult given that the current legislature need not collectively affect the agency to steer regulatory action. See Rodriguez, supra note 8, at 120-22. In other words, individual legislators-committee chairs, for instance-can attempt to influence agencies whether or not their views coincide with either the preferences of the enacting legislature or the preference of a majority of the current legislature. See generally CHRISTOPHER H. FOREMAN, JR., Signals fROM THE Hill (1988) (discussing congressional oversight of administrative agencies). 


\section{The President's Comparative Advantage}

The President's capacity to formulate strategies for reforming regulatory processes grows out of his unique institutional resources that give him at least the abilities-if not necessarily the incentives-to lead reform efforts. ${ }^{47}$ Some of these abilities arise from the fundamentals of institutional design. In contrast to any member of Congress, the President has a national constituency. Elected by 435 times as many citizens as each member of the House of Representatives and by 7 times as many citizens as the two senators in the largest state, the President has a constituent base tremendously larger than those of legislators. The nexus between size and diversity is complex, to be sure, but certamly the Framers understood that expanding the size of the franchise would enable pohticians to resist more effectively the "passions" and "interests" that plagued sunaller units of government. ${ }^{48}$

There are at least two ways in which the national constituency of the President may be, for him, a comparative advantage. First, he is more resilient politically than any member of Congress. Members of the House of Representatives and, albeit to a lesser extent, members of the Senate can less afford to antagonize interest groups with a stake in the particulars of a regulatory policy than can the President, who is less vulnerable to targeted appeals by interest groups to his constituents. Second, if we suppose that legislators invest their energies in representing, as a priority, the interests of their constituents, the legislature is properly understood as a diffuse and heterogeneous institution. ${ }^{49}$ Legislators trade votes and specialize on issues that are especially germane to their constituencies; the legislative process, then, appears as a complex mosaic of competing and collaborating lawmakers, each

47. See Terry M. Moe \& Scott A. Wilson, Presidents and the Politics of Structure, 57 LAW \& ContemP. ProbS., Spring 1994, at 1, 11; Terry M. Moe, Presidents, Institutions, and Theory, in Researching the Presidency 337, 363-64 (George C. Edwards, III et al. eds., 1993).

48. See The Federalist No. 10, at 83 (James Madison) (Clinton Rossiter ed., 1961) ("Extend the sphere and you take in a greater variety of parties and interests; you make it less probable that a majority of the whole will have a common motive to invade the rights of other citizens ...."); id. No. 51, at 325 (James Madison) ("In the extended republic of the United States, and among the great variety of interests, parties, and sects which it embraces, a coalition of a majority of the whole society could seldom take place on any other principles than those of justice and the general good . ...").

49. See ARNOLD, CONGRessional ACtion, supra note 27, at 60-118 (describing relationship between legislators' electoral calculations and their lawmaking decisions). 
with his own interests and agendas yet each with the incentives to form common ground in order to further the interests of his constituents and of the institution of which he is a part. ${ }^{50} \mathrm{By}$ contrast, the presidency is an institution led by one individual. The diffuse character of the legislature and legislative action, described above, presents an opportunity for a President who can act unilaterally. Not plagued by the difficulties associated with collective decisionmaking, ${ }^{51}$ the presidency is an institution of action, capable of responding in a certain voice.

Where the President can act without engaging the legislature and hence avoid the diffuse, multifaceted legislative process, he will most often do so. The structure of the NPR recommendations are telling in this regard. Nearly all the commission's proposals can be implemented either by agency heads alone or through presidential fiat. ${ }^{52}$ Only REG10.2, the proposed move of training programs for agency regulatory lawyers back to Washington, D.C., requires legislative action. ${ }^{53}$ Of course, the absence of proposals that require legislative action may be a refiection of the commission's unwillingness to engage Congress in a protracted struggle over regulatory reform. ${ }^{54}$ Yet, this is in and of itself significant. The President can move forward with reform strategies by bypassing Congress. Absent legislative action, the President can, as the NPR proposals demonstrate, still construct proposals for reshaping regulatory systems through devices such as executive orders and presidential directives.

Compared with initiatives that coine froin the ground up, that is, from the bureaucracy, presidential reforms can be much more sahent, affecting a larger stretch of the regulatory highway than can agency-led reforms. ${ }^{55}$ Significantly, the President sits atop the

50. See, e.g., Rodriguez, supra note 8, at 56-74; Barry R. Weingast \& William J. Marshall, The Industrial Organization of Congress; or, Why Legislatures, Like Firms, Are Not Organized as Markets, $96 \mathrm{~J}$. POL. ECON. 132 (1988).

51. See generally KENNETH J. ARROW, SOCIAL ChOICE AND INDIVIDUAL VALUES (2d ed. 1963) (detailing the formal elements and problems associated with collective social choice); DANIEl FARBer \& PHILIP FRICKEY, LAw AND PUBlic ChOICE $38-62$ (1990) (discussing the implications of social choice theories).

52. See IMPROVING REGULATORY SYSTEMS, supra note 10 , at 79.

53. See id. at 71-72. In the discussion at the Duke Law Journal Administrative Law Conference, Jeffrey Lubbers pointed out that this proposal is likely to generate resistance from Senator Ernest Hollings, whose intervention was responsible for moving the training program to South Carolina in the first place.

54. See, e.g., ARnold, MANAGerial Presidency, supra note 2, at 345-51 (describing dynamics of 20th-century reorganization efforts involving the President and Congress).

55. See supra text accompanying notes 24-28 (describing bureaucrats' short time hori- 
regulatory system as the leader of the federal bureaucracy. If anyone is positioned to coordinate diffuse regulatory policy, it is the President, as leader of the executive branch..$^{56}$ Coordination is made more difficult, naturally, by the existence of various independent agencies and commissions. And, of course, many elements' of the regulatory process-for instance, the structure of oversight hearings and the budgetary process - are wholly or partially within the domain of Congress and therefore not amenable to either management or control. Still, in an environment in which collaboration among the key institutions in government is unlikely and in which Congress cannot easily pursue regulatory initiatives by passing new statutes, the President's ability to undertake reform strategies through unilateral action of the sort reflected in the NPR proposals makes him qualitatively superior as a reform leader, as an instrument of systematic regulatory change.

To a great degree, of course, the President's unilateral initiatives are contingent on Congress not reacting to the President's reform strategies by defeating or preempting his efforts. When the President's proposals raise objections with Congress, legislators can interpose themselves between the President's reform strategies and the implementation of the proposals, even if congressional action is not required to move forward. ${ }^{57}$ Presidential initiatives take place in the context of legislative acquiescence; when, however, legislators oppose such initiatives, the domain of the President's

zon).

56. The extent to which the entire bureaucracy is part of a "unitary" executive remains controversial. See, e.g., Calabresi \& Rhodes, supra note 4, at 1186-208. For a thoughtful recent critique of one prominent effort to defend the concept of the unitary executive, see Lani Guinier, Lines in the Sand, 72 TEX. L. REV. 315, 334-47 (1993).

57. The battle waged during the last months of the Bush administration over the Competitiveness Council is instructive. Although President Bush required no legislative authorization to create the Council, which functioned similarly to the Office of Information and Regulatory Affairs during the Reagan presidency, Congress threatened the administration with cutting off funding for the Council. See Krauss, supra note 5, at A16. Moreover, more serious-but probably less credible-threats contemplated legislation that would have prohibited the Competitiveness Council from carrying out its regulatory functions. While debates concerning the legality of Congress's actions and, conversely, the legality of the President's decisions to create an institution such as the Competitiveness Council raged around the periphery, the core concern was whether the President's regulatory efforts would, however legitimate, survive the political onslaught of influential legislators who were persistently opposed to President Bush's innovations. See Rodriguez, supra note 8 , at $83-85$. 
practical authority to move forward unilaterally is, for better or worse, substantially limited.

With this description of the President acting in the shadow of legislators' political choices, we arrive at a core issue that has thus far remained latent in our discussion of institutional power. The comparative advantage of the President in leading regulatory reform turns on our assessments of how much authority the President brings to the enterprise. If, to take one extreme, we understand the President's role in regulation essentially as carrying out the expressed intent of the legislature, that is, we understand the President to be an agent of the legislature, we would have a considerably limited view of the potential for presidential leadership. A more capacious construction of the President's regulatory powers would, correspondingly, support an enriched view of the potential of the President as leader.

The proper scope of the President's powers-constitutional and statutory-in the regulatory process is a major subject in the contemporary literature on regulation and lawmaking in the modern administrative state. ${ }^{58}$ The debates, of course, are not new; they go back to the Constitution's framing and perhaps before that. Yet, the controversies have recently become much more palpable as recent Presidents have taken steps to expand their role in the regulatory process. ${ }^{59} \mathrm{I}$ do not want to enter into this debate here except to make two points. First, any prescriptions for regulatory reform that take into account (as they must) the dynamics of institutional decisionmaking and strategy must come armed with a theory of legislative and presidential power. Second, our sense of how and whether the President makes proper use of the regulatory power that he possesses depends in part on the specific strategy being furthered through the use of such power in connection with real regulatory decisions. The first point should be underscored by the discussion of institutional capacities in this Part of my Comment. The second point frames the discussion of the President's regulatory role in the next Part.

58. See, e.g., Lessig \& Sunstein. supra note 3; Bruff, supra note 1.

59. See, e.g., Sidney A. Shapiro, Political Oversight and the Deterioration of Regulatory Policy, 46 ADMIN. L. REV. 1 (1994) (describing, inter alia, the President's expanding role in regulatory processes). 


\section{CONCEPTIONS OF THE PRESIDENT'S ROLE IN REGULATION AND ITS REFORM}

Even if we conclude that the President has significant advantages over Congress and the bureaucracy in pursuing systematic regulatory initiatives, we should still try to be more precise, if possible, about what exactly presidential leadership in regulatory administration and government reform means. I will offer some thoughts about two strategies that form part of the basis of the President's regulatory reform: management and control.

\section{A. Management}

The management role of the President involves the modern chief executive's struggle to bring together the diffuse pieces of the far-flung regulatory system into some sort of coherence. ${ }^{60}$ To manage, $\dot{m}$ this sense, is to organize government into an appropriate structure to further particular purposes. ${ }^{61} \mathrm{He}$ may have many different purposes; what management as a presidential strategy connotes. is the use of certain types of techniques to reach governmental objectives.

Perhaps the President's main concern is with government efficiency, with reducing the burdens of regulatory policies on the private sector and the costs of running a regulatory system. ${ }^{62}$ Management strategies may be a set of means to reach that end. For example, government reorganization that reduces the number of executive branch departments and the amount of bureaucratic burdens imposed in regulatory decisions emerging from agency processes illustrates the use of a management technique to pursue efficiency. Through management devices, the President may also

60. This "management" conception has been examined in the political science literature on government reorganization. See, e.g., ARNOLD, MANAGERIAL PRESIDENCY, supra note 2; BARRY D. KARL, EXECUTIVE REORGANIZATION AND REFORM IN THE NEW DEAL (1963). It is also a core element in the vast literature on public administration and the role of executives and administrators in managing public enterprises. See, e.g., Laurence E. LynN, JR., Managing Public Policy (1987); Herbert Kaufman, The Administrative Behavior of Federal Bureau Chiefs (1981); Hal G. Rainey, Public Management: Recent Developments and Current Prospects, in PUBLIC ADMINISTRATION: THE STATE OF THE Discipline, supra note 40 , at $157,168-69$.

61. See Theodore J. Lowi, The Personal President 52-62 (1985) (describing emergence of presidential management and the end of "Congress-centered" government).

62. See, e.g., Verkuil, supra note 39 , at 4. 
organize component parts of government for the purpose of meeting the government's regulatory objectives. This is the model of the President as ensuring that the trains run on time, or, for example that the Department of Housing and Urban Development is the suitable organization to implement certain public policies and that it has adequate resources for this purpose. The purpose of management is in such case to structure the diffuse elements of the administrative system suitably to carry out its goals.

In another view, the President's role, consistent with his constitutional responsibility to see that the laws are "faithfully executed," $" 63$ is to manage the regulatory system in order to ensure that it is an optimal engine for the proper implementation of congressional policies. For instance, presidential scrutiny of proposed administrative regulations may be seen as a device for ensuring that the agency has not strayed from its statutory instructions. Presidential management of the regulatory process is employed to create another checkpoint in the far-flung regulatory system. In this view, the President does not manage in order to lead; instead, he manages in order to follow. ${ }^{64}$

There are no doubt other views of presidential management one could construct. Moreover, there are certainly more richly developed ideas of presidential management in the literature on organization theory and public administration than I will do justice to here. ${ }^{65}$ My main aim is to offer a conception of the President's role in regulation and its processes that is distinct from a second aspect of his role that I describe as presidential control.

\section{B. Control}

Besides management strategies, which reflect a sort of instruinental rationality whereby the President constructs techniques for

63. U.S. CONST. art. II, § 3.

64. Of course, the notion that the chief executive should function as a mere instrument of the legislature and that, therefore, he should have no discretion in the course of exercising his "executive" functions is controversial. For a rich, theoretical discussion of executive leadership that takes issue with this mechanical conception, see HARVEY C. Mansfield, JR., Taming the Prince: The ambivalence of Modern Executive POWER 181-278 (1989).

65. See, e.g., Lynn, supra note 60; Kaufman, supra note 60; Rainey, supra note 60, at 168-69;. For an extremely interesting, yet distinct, discussion of "management" from the perspective of First Amendment law, see Robert C. Post, Between Governance and Management: The History and Theory of the Public Forum, 34 UCLA L. REV. 1713, 1788-93 (1987. 
organizing and supervising the bureaucracy to reach governmental objectives, the President also has an interest in controlling the bureaucracy. The sine qua non of control is presidential opportunism, that is, the taking advantage of regulatory and governmental processes for individual political ends. ${ }^{66}$

In attributing to the President the motive of opportunism, I am making a claim about the shape of the President's incentives as well as his ability to act purposively-or what I sometimes call politically-to accomplish his individual goals. The claim is that the President is like any other actor in the political process in that he makes rational choices concerning policy outcomes, the structure of policy processes, and, where he has the authority, the design and function of the institution of which he is a part. These rational choices may be directed toward salutary or pernicious ends. He may act purposively and powerfully to better lead the nation. On the other hand, he may aggrandize himself by usurping the regulatory powers of other institutions (Congress, the bureaucracy, or the courts) to further his own political ends.

The strategy of control, like management, is a mechanism the President employs to reach certain ends. How control differs from management, though, is that through control strategies the President acts to expand the scope of his own power. For that reason, control tactics are frequently unilateral. He reduces the scope of legislative or bureaucratic power or takes advantage of existing institutions and institutional devices to facilitate his own aims. Accordingly, 'the consequence of successful presidential control is usually the weakening of the powers and abilities of other political actors with which the President competes. ${ }^{67}$

When the President is acting to exercise control and influence over regulatory policy, he is exercising power, or perhaps more accurately, he is creating power and the opportunities for its exercise. Through control, he can replace the will of agencies with his own will. If, however, regulatory agencies are acting as agents of their principals in the legislature and therefore are reflecting the will of the legislature rather than their own, then the President's strategies of control are carried out with an eye toward replacing legislative preferences with his own. The critical point is that the President, through various control devices, in such cases uses his

66. See Rodriguez, supra note 8 , at $81-84$.

67. See id. at 106-11. 
office to interpose himself between legislators' preferences as reflected in their directions to administrators as well as the preferences of the admmistrators themselves. ${ }^{68}$ As with any other source of power, it need not be frequently exercised; the threat of control may be sufficient to facilitate the President's aims with low cost.

The President aims to influence the outcomes of regulatory policies through the exercise of power over agencies and their staffs. This exercise may be latent or express; in other words, the President may scrupulously guard prerogatives to control agencies whether or not he utilizes these prerogatives in a routine fashion. For instance, the President may fight to retain the power to remove unilaterally heads of agencies whether or not he is, in any specific case, willing to bear the political risks of actually removing the agency head. He also may struggle to control the flow of mformation to other branches of government-say, by invoking executive privilege to resist dissemination of documents to Congress-even though it may be politically necessary to comply with congressional directives in most cases.

Thus defined, discerning whether a President is acting in order to control, rather than to manage, requires us to excavate his objectives. Two things can be said about particular presidential techniques. First, certain mechanisms of presidential participation in regulatory processes are more consistent with the idea that the President is employing this device opportunistically, with an eye toward fulfilling his own political ends, and other mechanisms are more consistent with the idea of the President as a manager of regulatory processes. For example, the effort by President Reagan's transportation secretary, Andrew Lewis, to influence the Federal Labor Relations Authority to decertify the air traffic controllers union reflects opportunistic presidential behavior directed toward influencing the outcome of regulatory policies. ${ }^{69}$ Such efforts are hardly what we would consider to be part of a system of presidential management of administration. ${ }^{70}$

68. For a description of how one of these control devices-control over the processes of statutory interpretation-operates, see Daniel B. Rodriguez, Statutory Interpretation and Political Advantage, 12 INT'L REV. L. \& ECON., 217, 226-28 (1992).

69. See Professional Air Traffic Controllers Org. v. FLRA, 685 F.2d 547, 568 (D.C. Cir. 1982).

70. But see Sierra Club v. Costle, 657 F.2d 298, $406-08$ (D.C. Cir. 1981) (upholding presidential ex parte intervention in pending regulatory proceeding). 
Second, there are presidential techniques that are consistent with both management and control strategies as I have defined them here. Take, for example, the efforts by Presidents Reagan and Bush to subject proposed regulations to review by an executive department (with Reagan it was the OMB) or council (with Bush it was the Competitiveness Council). ${ }^{71}$ The expressed purpose of regulatory review as practiced in these administrations was to restrain agencies from promulgating regulations whose costs-in the judgment of the reviewing bodies-exceeded their benefits. ${ }^{72}$ Yet, this purpose jibes with a presidential strategy of derailing regulatory agencies and imposing a requirement of cost-benefit analysis to delay or disrupt regulatory policymaking, ${ }^{73}$ it also jibes with a strategy of managimg admimistrative agencies to make sure that they do not stray from the statutory purposes expressed by Congress. ${ }^{74}$ To know whether regulatory review of the sort practiced by Presidents Reagan and Bush was part of a strategy of control or management-and to know what precisely we think about the prudence and legality of such strategies in any case-we need to know the objectives of such strategies. We are therefore brought back full circle to the central normative question underlymg presidential leadership in administration: to what ends have recent Presidents, including Clinton, been expanding their role in the regulatory process?

\section{PRESIDENTIAL LEADERSHIP AND \\ REGULATORY REFORM: SOME LESSONS FROM THE CLINTON-GORE PLAN}

The presidency, says Yale political scientist Stephen Skowronek, "defies subtlety." As an institution, it is a "battering

71. See supra notes 5,57 (discussing OMB and Competitiveness Council).

72. See Exec. Order No. 12,291, 3 C.F.R. 127 (1981), reprinted in 5 U.S.C. \& 601 (1988).

73. See, e.g., Alan B. Morrison, OMB Interference with Agency Rulemaking: The Wrong Way to Write a Regulation, 99 HARV. L. REV. 1059, 1064, 1064-71 (1986) ("[T] system of OMB control imposes costly delays that are paid for through the decreased health and safety of the American public.").

74. See Christopher C. DeMuth \& Douglas H. Ginsburg, White House Review of Agency Rulemaking, 99 HARV. L. REV. 1075, 1081-82 (1986) ("Centralized review of proposed regulations under a cost/benefit standard ... encourages policy coordination, greater political accountability, and more balanced regulatory decisions.").

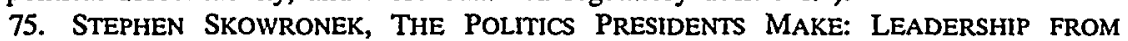


ram, and the presidents who have succeeded most magnificently in political leadership are those who have been best situated to use it forthrightly as such." ${ }^{.76}$ Measured against the Clinton administration's efforts in its project to "improve regulatory systems," this description seems to cast Clinton in the role of the moderate, cautious tinkerer.

This is a plausible description of the NPR project. The scope of the plan is indeed limited in important respects. To begin with, there are two areas the NPR Report steers clear of altogether. One is the system of legislative budgeting for regulatory programs. Proposals for changes in the way regulatory programs are budgeted, though prominent in previous administrations' reform proposals, ${ }^{77}$ are left out of the Clinton-Gore plan. Part of the explanation, perhaps, is that considering the methods of regulatory budgeting would create controversies within government over the scope and costs of regulatory programs that would, at the very least, require more sustained collaboration with Congress and the agencies and, at the most, severely jeopardize the reform efforts that the plan describes. ${ }^{78}$ Second, the "D word"-deregulation-is featured nowhere in the NPR Report. ${ }^{79}$ Although elsewhere in the area of domestic policy, President Clinton has sounded sympathetic to Republican calls for paring federal governmental programs (welfare policy is the most notable instance), ${ }^{80}$ the NPR project does not embark on the task of proposing substantial reductions in the scope of the modern administrative state.

The dominant theme of the Clinton-Gore proposals is more effective management by the President in order to improve gov-

\footnotetext{
JOHN ADAMS TO GEORGE BUSH 24 (1993).

76. Id. at 28 .

77. See ARnold, Managerial Presidency, supra note 2, at 231-32, 316 (discussing efforts of Presidents Johnson and Carter to reform system of agency regulatory budgeting).

78. There is, however, a note in the NPR Report that suggests that budgeting may be considered in another part of the project. See IMPROVING REgulatory SYSTEMS, supra note 10 , at 3 n.1. Without having reviewed these other reports, I still think it unlikely that the NPR has considered systematically issues of regulatory budgeting in the course of its studies and recommendations.

79. Perhaps, though, one can regard REG07 ("Rank Risks and Engage in Anticipatory Regulatory Planning") as promoting deregulation to the extent that it encourages agencies to prioritize when deciding whether and to what extent to regulate certain risks. See id. at 53-57.

80. See, e.g., President's State of the Union Address, 30 WeEkLY COMP. Pres. Doc. 4 (Jan. 31, 1994).
} 
ernment efficiency. The NPR proposals resonate with the tone of good government and efficiency. As the NPR Report concludes: "The President's plan provides a regulatory process that works for the American people, not against them . . . It is aimed at producing regulations that are effective, consistent, and understandable." ${ }^{81}$ This is not exactly a description of a regulatory revolution. Rather, it invokes a vision of the administration as improving the management of federal regulation and its processes. For instance, the NPR proposals for "direct final" rules and for alternative dispute resolution, or "reg neg," 82 are well within the conception described above of the President as efficient manager of the executive branch. ${ }^{83}$

Describing the Clinton-Gore strategy as concerned "merely" with regulatory efficiency and cost-effectiveness is not a criticism; in and of itself, the strategy of improving regulatory efficiency may not be inconsistent with a conception of the President as a "battering ram," as pursuing comprehensive reform as part of his presidential leadership. Improving regulatory performance may enable the President to pursue other aims without the investment otherwise required for managing the federal bureaucracy. Moreover, some of the proposals for encouraging better regulatory approaches are tied to government philosophies that stress the economic advantages of reducing the cost and improving the effectiveness of regulation. ${ }^{84}$ And it may be precisely these same philosophies that undergird the President's desire to control more effectively the federal bureaucracy.

Are there any elements in the NPR Report that evince President Clinton's interest in strategies of control? Although the report is mostly a paean to effective administrative management, the commission goes to great lengths to proffer proposals that require no legislative assent. The proposals can be implemented, for the most part, unilaterally by the President. ${ }^{85}$ Pursuing regulatory initiatives without involving the legislature to a great extent is a common technique of presidential control. It is not that it is mere-

81. IMPROVING REGULATORY SYSTEMS, supra note 10 , at 77.

82. See id. at 47.

83. See supra text accompanying note 62 (describing presidential management toward the goal of efficiency).

84. See, e.g., BREYeR, Vicious CIRCLE, supra note 22. at 3-29; SUNSTEIN, RightS REVOLUTION, supra note 6, at 74-110.

85. See IMPROVING REGUlatORY SYSTEMS, supra note 10, at 79. 
ly more efficient to implement strategies unilaterally; it also has the effect of stealing the legislature's thunder by establishing a decisive presidential role in regulatory reform and improvement. To be sure, Congress can respond with its own reform proposals, and it can replace these initiatives seriatim or comprehensively by statute. Yet, the mere fact that the legislature must respond with its own reform strategies if it intends to compete with the President for credit, or even if it wants to establish its own vision of proper regulatory reform simply because it prefers its program to the President's illustrates the advantage to President Clinton of taking the initiative on this reform issue. Hence, even these moderate proposals may reflect, in their structure, the President's interest in controlling the reform agenda. As with the example of regulatory review under Presidents Reagan and Bush discussed above, ${ }^{86}$ the NPR project can be understood as consistent with both conceptions of the President's regulatory role.

On balance, President Clinton's formula for remaking regulation as elaborated in the NPR project is only moderately ambitious. It neither reconstructs the basic framework of federal regulation and its administration nor presses forward with attempts to strengthen his authority and increase his opportunities to lead and to govern. As an expression of a philosophy of government, the theme of the NPR project is efficiency in regulatory administration; as an expression of a philosophy of presidential leadership, its theme is that the President is willing to move forward with regulatory initiatives incrementally, in small policy steps. Citing this limited set of initiatives as evidence that the President is shying away from a more ambitious, reconstructive political strategy is premature, though. For even as the Clinton administration is feeling its way toward developing its strategy and approaches for both managing and controlling the modern federal bureaucracy, the President has preserved his options by shrewdly maintaining the mechanisms for presidential leadership that proved so useful for his predecessors in. the Oval Office.

\section{CONCLUSION}

Calls for improving regulatory systems have increasingly been directed toward the President. At the same time, a chorus of

86. See supra text accompanying notes $71-74$. 
critics have objected to what they have regarded as the efforts of the President to exploit the bureaucracy to serve his own political and ideological ends. ${ }^{87}$ Both these positions have merit. The President does have special capacities, drawn from the structure of the executive branch and from the weaknesses endemic in other political institutions, to exercise a positive, significant role in improving regulatory performance. A strong presidential role entails risks, though. We have returned to the dilemma at the root of theories of presidential power in modern government: We purchase strong presidential leadership at the price of increased risks of the President exploiting the mechanisms of government for his own ends.

I have recast this dilemma in terms of presidential strategies in regulatory decisionmaking. The President manages and also controls. When we think about possible legal and political strategies to deal with these twin mechanisms-a subject that is beyond the scope of this Comment-we need to understand that both are core elements of presidential leadership, elements that are not easily separated, and that therefore it is not easy to restrain the President's power to control without, in the process, limiting his power to manage. Restricting the bad aspects of presidential leadership in regulation without surrendering the good aspects is the main challenge for prescriptive public law theory on the presidency and public administration.

87. See, e.g., Shapiro, supra note 59, at 11-13, 21-26. 